\title{
Looking forward to the power of a small grain
}

Bo-Hyoung Jin

Editor-in-Chief, The Journal of Korean Academy of Oral Health

As we welcomed the new year of 2020, many people probably reminisced the past, to a time when 2020 seemed far into the future. We may have envisioned a world with inconceivable innovations, which is why the beginning of 2020 may have brought strange sentiments to some. Instead of flying cars in the sky and people dressed in spacesuits, 2020 seemed to begin with a more familiar appearance than we had imagined.

However, 2020 definitely, from the beginning, started off differently. We are now so accustomed to the procession of people in masks and have lost the repulsion to the phrase "social distancing" and conformed to it instead.

Cholera, South Korea's first legal communicable disease, began in India and caused a worldwide pandemic. By 1923, six subsequent pandemics claimed the lives of millions around the world, including in Asia, Africa, Europe, and North and South Africa. Cholera can be caused by raw or undercooked seafood and can occur when cooking or eating food with contaminated hands. Food or water contaminated by feces or vomit can also cause infection, which threatens the health of humanity to this day.

We should refer to Dr. John Snow (1813-1858), who highlighted the problem of contaminated drinking water sources to address the cholera outbreak in England. Through his epidemiological investigation analyzing the pattern of disease outbreaks and tracking down causes, he suggested ways to save humans from terrifying plagues. In addition, the fact that the largest response to BMJ's question to 11,000 readers around the world for the greatest advances in medicine was that 'public hygiene' is recommended for many things.

The current Coronavirus Infectious Disease-19 (COVID-19) is believed to be transmitted through secretions such as patients' saliva droplets, and is also known to progress to lower respiratory tract infections leading to pneumonia or death. Considering the path of the infection through patients' saliva droplets, we must take preventative measures not only from the perspective of public health, but also from the perspective of fulfilling national oral health objectives. I believe that members of the academy who are majoring in preventive dentistry and public oral health should also take interest and continue research on preventing infectious diseases such as COVID-19.

Just as a small grain of wheat will sprout, one day our small research findings will converge to save humanity from disease. The future will be created through our efforts, and we must each make relentless efforts toward it.

I look forward to this present period becoming the past.

March 2020 


\section{작은 밀알의 힘을 기대하며}

진보형

대한구강보건학회지 편집이사

2020년을 맞이하여 많은 사람들은 잠시 과거로 여행을 떠났을 것이다. 우리에게 2020년은 아주 먼 미래였고, 우리가 상상할 수 없는 혁신적 인 모습으로 그려지곤 했기에 2020년을 맞이하는 우리는 그 감회가 남달랐을 것이다. 그러나 하늘로 날아다니는 차, 우주복을 입고 다니는 사람 들로 그려졌던 2020년은 우리가 상상했던 모습보다는 너무나도 우리에게 익숙한 모습으로 그 시작을 알리는 것 같았다.

그러나, 확실히 2020년은 시작부터 다름을 알리기 시작했다. 이제는 너무나 익숙해진 마스크 쓴 이들의 행렬과 '사회적 거리두기'라는 말에 대한 거부감도 사라지고 이에 순응하는 모습을 보게 된다.

우리나라의 제 1 법정 전염병인 콜레라는 1817 년에 인도에서 시작하여 세계적인 대유행을 일으켰으며, 1923년까지 6차례의 대유행을 통해 아시아 아프리카 유럽 남북아메리카 등 전 세계에 걸쳐 수많은 인명을 앗아갔다. 콜레라균은 날 것 또는 덜 익은 해산물이 감염 원인이 될 수 있으 며, 오염된 손으로 음식을 조리하거나 섭취할 때 발생할 수 있다. 또는 분변, 구토물로 오염된 음식이나 물을 통해 감염되며, 이는 아직까지도 인 류의 건강을 위협하고 있다.

여기서 우리는 영국에서 발생된 콜레라를 해결하기 위해 오염된 식수원의 문제를 지적한 의사 존 스노우(Dr. John Snow, 1813-1858)를 주 목해 봐야 한다. 그는 질병 발생 양상을 분석하고, 이의 원인을 추적해 나가는 역학 조사를 통해, 무서운 역병에서 인간을 구하는 방법을 제시하였 다. 또한, 영국의사협회지가 전 세계 1 만 천명의 독자에게 의학상의 위대한 진보를 묻는 질문에 대해 제일 많은 응답이 '공중 위생’이었다는 것은 시사하는 바가 크다.

이번 코로나바이러스 감염증-19 (COVID-19)는 환자의 침방울 등의 분비물을 통해 감염되는 것으로 추정되며, 하기도 호흡기 감염으로 진행 되어 폐렴이나 사망에 이르는 것으로 알려져 있다. 환자의 비말 등을 통한 감염 경로를 고려할 때, 공중위생뿐만 아니라 공중구강보건의 측면에서 도 이의 예방을 위해 노력해야 하는 부분이 많다고 생각된다. 이는 예방치학과 공중구강보건학을 전공하는 우리 학회 회원들도 관심을 가지고 이 와 같은 전염병의 예방을 위해 연구해 나가야 할 것으로 생각되어진다.

한 알의 작은 밀알이 싹을 틔우듯이 언젠가 우리들의 작은 연구결과가 모여 인류를 질병에서 구할 수 있는 시기가 올 것이다. 다가올 미래는 우리의 이런 노력이 모여서 이루어지리라고 생각되며 모두 끊임없는 노력을 경주해야 한다.

아무쪼록 현재의 이런 시기가 하루 빨리 과거의 이야기가 되는 날이 오기를 기대해 본다.

2020. 3 . 